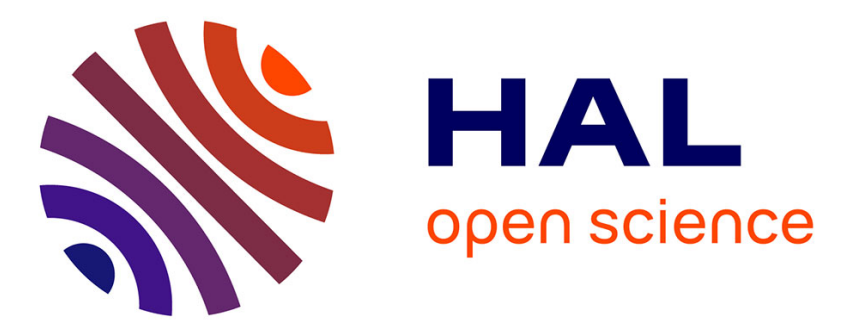

\title{
Low-Cost and Facile Synthesis of the Vanadium Oxides V2O3, VO2, and V2O5 and Their Magnetic, Thermochromic and Electrochromic Properties.
}

Issam Mjejri, Aline Rougier, Manuel Gaudon

\section{- To cite this version:}

Issam Mjejri, Aline Rougier, Manuel Gaudon. Low-Cost and Facile Synthesis of the Vanadium Oxides V2O3, VO2, and V2O5 and Their Magnetic, Thermochromic and Electrochromic Properties.. Inorganic Chemistry, 2017, 56 (3), pp.1734-1741. 10.1021/acs.inorgchem.6b02880 . hal-01475536

\author{
HAL Id: hal-01475536 \\ https://hal.science/hal-01475536
}

Submitted on 23 Feb 2017

HAL is a multi-disciplinary open access archive for the deposit and dissemination of scientific research documents, whether they are published or not. The documents may come from teaching and research institutions in France or abroad, or from public or private research centers.
L'archive ouverte pluridisciplinaire HAL, est destinée au dépôt et à la diffusion de documents scientifiques de niveau recherche, publiés ou non, émanant des établissements d'enseignement et de recherche français ou étrangers, des laboratoires publics ou privés. 


\title{
Low cost and facile synthesis of various vanadium oxides: $\mathrm{V}_{2} \mathrm{O}_{3}, \mathrm{VO}_{2}$ and $\mathrm{V}_{2} \mathrm{O}_{5}$ and their magnetic, thermochromic and electrochromic properties.
}

\author{
Issam Mjejri $^{\dagger, \ddagger}$, Aline Rougier ${ }^{\dagger, \ddagger}, *$, Manuel Gaudon ${ }^{\dagger, *}$ \\ 'CNRS, ICMCB, UPR 9048, F-33600 Pessac, France \\ Univ. Bordeaux, ICMCB, UPR 9048, F-33600 Pessac, France \\ *Corresponding Author: aline.rougier@ icmcb.cnrs.fr, ICMCB-CNRS, 87 avenue du Dr Albert Schweit- \\ zer, 33608 Pessac cedex, France
}

KEYWORDS. X-Polyol synthesis; Vanadium oxides; Magnetism; Thermochromism; Electrochromism; MetalInsulator Transition (MIT).

\begin{abstract}
In this study, vanadium sesquioxide: $\mathrm{V}_{2} \mathrm{O}_{3}$, dioxide: $\mathrm{VO}_{2}$ and pentoxide: $\mathrm{V}_{2} \mathrm{O}_{5}$ were all synthesized from one single polyol route through the precipitation of an intermediate precursor: vanadium ethyleneglycolate (VEG). Various annealing treatments of the VEG precursor, under controlled atmosphere and temperature, lead to the successful synthesis of the three pure oxides, with submicronic crystallite size. To the best of our knowledge, the synthesis of the three $\mathrm{V}_{2} \mathrm{O}_{5}, \mathrm{VO}_{2}$ and $\mathrm{V}_{2} \mathrm{O}_{3}$ oxides from one single polyol batch has never been reported in the literature. In a second part of the study, the potentialities opened by the successful preparation of sub-micronic $\mathrm{V}_{2} \mathrm{O}_{5}, \mathrm{VO}_{2}$ and $\mathrm{V}_{2} \mathrm{O}_{3}$ are illustrated by: the characterization of the electrochromic properties of $\mathrm{V}_{2} \mathrm{O}_{5}$ films, a discussion about the metal to insulator transition of $\mathrm{VO}_{2}$ based on in situ measurements versus temperature of its electrical and optical properties, the characterization of the magnetic transition of $\mathrm{V}_{2} \mathrm{O}_{3}$ powder from squid measurements. For the latter compound, the influence of the crystallite size on the magnetic properties is being discussed.
\end{abstract}

\section{Introduction}

To date, numerous researchers have spent great efforts in searching for transition metal oxides with diverse properties ${ }^{1-6}$. Vanadium oxides are a family of interesting materials with high catalytic, electrical, optical and magnetic properties and potential applications such as batteries 7-16 electrochromic devices ${ }^{17-22}$ and thermochromic smart windows ${ }^{23-26}$. Indeed, the multivalent nature of vanadium cation gives it distinct colors, which earn it the name of the Norse Goddess of beauty, Vanadis. Vanadium element exists in several oxidation states, namely $\mathrm{V}^{3+}, \mathrm{V}^{4+}$ and $\mathrm{V}^{5}$, allowing the formation of several oxides with exciting properties combining structural transformations and optical, magnetic or electronic modifications ${ }^{27}$. As examples, both vanadium dioxide $\left(\mathrm{VO}_{2}\right)$ and sesquioxide $\left(\mathrm{V}_{2} \mathrm{O}_{3}\right)$ show metal-to-insulator transition (MIT), which implies an abrupt change in optical and electrical properties ${ }^{27},{ }^{28}$. This work focuses on the study of the oxides $\mathrm{VO}_{2}, \mathrm{~V}_{2} \mathrm{O}_{3}$ and $\mathrm{V}_{2} \mathrm{O}_{5}$ to demonstrate the diversity of some of the physico-chemical properties of vanadium oxides (magnetic properties for $\mathrm{V}_{2} \mathrm{O}_{3}$, thermochromic properties for $\mathrm{VO}_{2}$ and electrochromic properties for $\mathrm{V}_{2} \mathrm{O}_{5}$ )

Orthorhombic vanadium pentoxide $\left(\mathrm{V}_{2} \mathrm{O}_{5}\right)$ is the "oxygen saturated state" (highest oxidation state for vanadi- um) in the $\mathrm{VO}_{\mathrm{x}}$ system, and consequently the most stable one. It has attracted a considerable interest due to its interesting physical properties. Because of its anisotropic structural framework based on penta-coordinated vanadium (with square pyramid geometry), forming a "lamellar" structure (planes of edge sharing pyramids isolated from each other with a interlayer length about $4 \AA$ ), $\mathrm{V}_{2} \mathrm{O}_{5}$ is one of the most popular material for electrochromic applications $17,18,22,29-33$. Indeed, facile intercalationdesintercalation of $\mathrm{Li}^{+}$ions into the $\mathrm{V}_{2} \mathrm{O}_{5}$ interlayer spaces leads to redox phenomena associated with reversible changes of the optical properties. As far as we know, vanadium pentoxide is the typical oxide that shows both anodic and cathodic colorations, even if the literature pointed up other compositions such as mixed oxides based on vanadium 34-37 thus offering the possibility of obtaining multicolor displays ${ }^{30-33}$. However, the lithiation process in $\mathrm{V}_{2} \mathrm{O}_{5}$ bulk is reported to be relatively limited due to a combination of low electrical conductivity $\left(10^{-3}-\right.$ $\left.10^{-2} \mathrm{~S} . \mathrm{m}^{-1}\right)$ and small $\mathrm{Li}^{+}$diffusion coefficients $\left(10^{-13}-10^{-12}\right.$ $\left.\mathrm{cm}^{2} . \mathrm{s}^{-1}\right)^{29-31,33}$.

Vanadium dioxide $\left(\mathrm{VO}_{2}\right)$ is a phase transition material, which undergoes a reversible (MIT) near $68^{\circ} \mathrm{C}$, accompanied by a reversible structural transition from the mono- 
clinic phase (at low temperature) to the tetragonal form (rutile type at high temperature). This transition is not only marked by an abrupt change of conductivity but also by a significant modification of the optical properties ${ }^{38-42}$. This remarkable behavior has sparked immense interest and $\mathrm{VO}_{2}$ is actively explored for potential applications ranging from ultra-fast nanoelectronic switches, transistors, thermoelectric devices and thermochromic smart windows ${ }^{23-25,41,42}$.

Finally, vanadium sesquioxide $\left(\mathrm{V}_{2} \mathrm{O}_{3}\right)$ exhibits a (MIT) coupled with a magnetic disordering versus temperature in heating mode ${ }^{43}$. At room temperature, $\mathrm{V}_{2} \mathrm{O}_{3}$ crystal framework exhibits a paramagnetic behavior associated with a metallic conduction type (PM) and transforms to an antiferromagnetic insulator (AFI) near $150 \mathrm{~K} 3^{-45}$. This interesting magnetic transition is correlated with a structural transformation from rhombohedral symmetry at room temperature to a monoclinic structure below the transition temperature ${ }^{46}$.

Several synthetic routes such as microemulsionmediated systems ${ }^{47}$, sol-gel ${ }^{48}$, solvothermal and hydrothermal methods ${ }^{10,12,15,49}$ have been successfully explored to fabricate different kinds of nanostructured vanadium oxides. Indeed, whatever the $\mathrm{VO}_{\mathrm{x}}$ oxide stoichiometry, the morphology of the synthesized $\mathrm{VO}_{\mathrm{x}}$ plays a great role on its potentialities besides the final application. For illustration, in comparison with $\mathrm{V}_{2} \mathrm{O}_{5}$ bulk, nanostructured $\mathrm{V}_{2} \mathrm{O}_{5}$ is characterized by a large electrochemical surface area and good interconnectivity for electronic conductivity ${ }^{21}$. In the literature, vanadium pentoxide films have been prepared using various physical and chemical techniques such as, thermal evaporation, electron beam evaporation, magnetron sputtering, sol-gel, electrochemical deposition and pulsed laser ablation ${ }^{50-52}$. Among several deposition techniques, Doctor Blade processes present the advantage of high versatility, low cost, reasonable deposition rates and simplicity in experimental parameters modulation ${ }^{6}{ }^{53}$. Obviously, the electrochromic performances of $\mathrm{V}_{2} \mathrm{O}_{5}$ thin films depend on several parameters including the film morphology, thickness, and so the coating process. For Doctor Blade deposited films, the electrochromic properties are mainly dependent on the oxide particle size of the powder dispersed in the coated suspension. Thus, the preparation of vanadium pentoxide from a synthesis route able to provide materials (low temperature route / soft chemistry route) with a large surface area for fast ion transport and good interconnectivity for electronic conductivity is highly desirable. Similarly, the MIT transition for both $\mathrm{V}_{2} \mathrm{O}_{3}$ and $\mathrm{VO}_{2}$ oxides is closely linked to the crystallite size and shape 54,55.

In this study, the vanadium sesquioxide, $\mathrm{V}_{2} \mathrm{O}_{3}$, dioxide, $\mathrm{VO}_{2}$, and pentoxide, $\mathrm{V}_{2} \mathrm{O}_{5}$ were all synthesized from one single polyol route. This recently developed process is ideal for the processing of very fine powders having high purity, high crystallinity, excellent reproducibility, narrow particle size distribution, uniformity, high reactivity since relatively low temperatures are required to achieve the various target oxide compositions $33,56,57$. Besides, $\mathrm{V}_{2} \mathrm{O}_{5}$ and $\mathrm{VO}_{2}$ have been also successfully elaborated in a largescale by solid-state transformation of single precursor vanadium complex via a facile hydrothermal approach ${ }^{58}$ but $\mathrm{o}$ the best of our knowledge, the synthesis of the three $\mathrm{V}_{2} \mathrm{O}_{3}, \mathrm{VO}_{2}$ and $\mathrm{V}_{2} \mathrm{O}_{5}$ oxides from one single polyol batch leading to the precipitation of an intermediate precursor : the vanadium ethyleneglycolate (VEG) has never been reported in the literature.

\section{Experimental details}

II.1. Polyol synthesis and physico-chemical characterizations of $V O_{x}$ oxides

All of the chemical reagents were purchased from Acros Organics and used without further purification steps. Ammonium metavanadate $\left(\mathrm{NH}_{4} \mathrm{VO}_{3}\right)$ was used as vanadium source and ethylene glycol $\left(\mathrm{H}_{6} \mathrm{C}_{2} \mathrm{O}_{2}\right)$ as template. In a typical synthesis, $\mathrm{NH}_{4} \mathrm{VO}_{3}(2.924 \mathrm{~g})$ was added to $250 \mathrm{~mL}$ $\mathrm{H}_{6} \mathrm{C}_{2} \mathrm{O}_{2}$. The resulting mixture was heated to $110{ }^{\circ} \mathrm{C}$ under continuous stirring to obtain a yellow sol refluxed at 160 ${ }^{\circ} \mathrm{C}$ for $1 \mathrm{~h}$. At the end of the reaction, a vanadylglycolate (VEG) precipitate was obtained. The precipitate was centrifuged and washed several times with ethanol to remove the organic product and dried in an oven at $80{ }^{\circ} \mathrm{C}$. To synthesize the final $\mathrm{V}_{2} \mathrm{O}_{5}, \mathrm{VO}_{2}$ and $\mathrm{V}_{2} \mathrm{O}_{3}$ powders, the VEG precursor was annealed at $500{ }^{\circ} \mathrm{C}$ for 2 hrs under air, vacuum $\left(\mathrm{PO}_{2} \approx 2.10^{-5} \mathrm{~Pa}\right)$ and a $95 \% \mathrm{Ar} / 5 \% \mathrm{H}_{2}$ gas mixture, respectively. Investigating the influence of the crystallite size on the magnetic properties, half of the $\mathrm{V}_{2} \mathrm{O}_{3}$ powder was submitted to an additional annealing under a $95 \% \mathrm{Ar} / 5 \% \mathrm{H}_{2}$ gas mixture for $5 \mathrm{~h}$ at $1000{ }^{\circ} \mathrm{C}$

The polyol processes and conditions used to synthesize the various $\mathrm{VO}_{\mathrm{x}}$ oxides are schematized in the Figure 1.

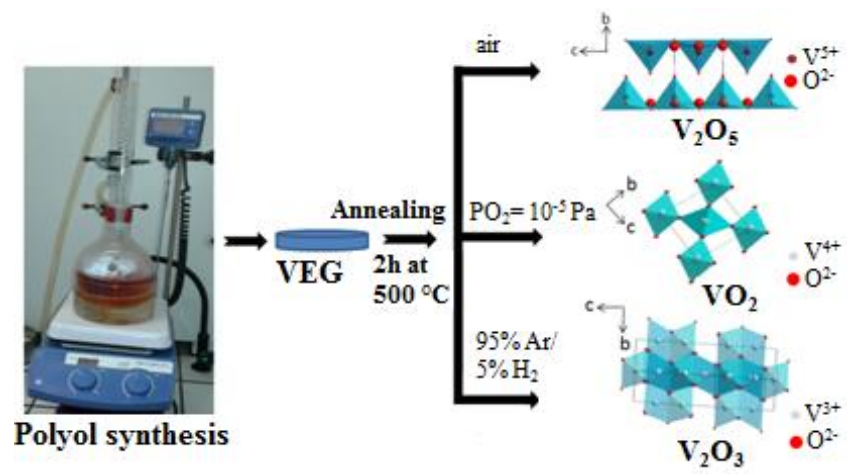

FIGURE 1. Scheme of the polyol process used for the synthesis of vanadium pentoxide $\mathrm{V}_{2} \mathrm{O}_{5}$, vanadium dioxide $\mathrm{VO}_{2}$ and vanadium sesquioxide $\mathrm{V}_{2} \mathrm{O}_{3}$ powders.

The powders structure was characterized by X-ray diffraction analysis (Philips PW 1820, PANalytical X'Pert instrument, $2 \theta$ range from 10 to $60^{\circ}$ and $\lambda_{\text {CuKol }}=1.54056 \AA$ ). Transmission electron microscopy (TEM) images were recorded with JEOL JSM-670oF (operating at $5 \mathrm{kV}$ ) microscope. 
II.2. Electrochromic measurements of $\mathrm{V}_{2} \mathrm{O}_{5}$ films

$\mathrm{V}_{2} \mathrm{O}_{5}$ films were deposited on $\mathrm{In}_{2} \mathrm{O}_{3}: \mathrm{Sn} /$ glass, ITO/glass, by "Doctor Blade" from the powder synthesized by the polyol method. Firstly, $80 \mathrm{mg}$ of powder was dispersed into $3 \mathrm{ml}$ distilled water. The resulting dilute was stirred for 3 days at room temperature and after aliquots of the as-prepared colloidal $\mathrm{V}_{2} \mathrm{O}_{5}$ solution was deposited on the ITO coated glass. The thickness of the $\mathrm{V}_{2} \mathrm{O}_{5}$ films, measured using a Dektak mechanical profilometer, was of about $900 \mathrm{~nm} \pm 50 \mathrm{~nm}$.

Electrochemical measurements were carried out in a three electrodes cell configuration using a BioLogic $\mathrm{SP}_{50}$ potentiostat/galvanostat apparatus and $\mathrm{V}_{2} \mathrm{O}_{5}$ films on ITO/glass as working electrode. The counterelectrode and reference electrode consisted of a platinum foil and Saturated Calomel Electrode, SCE ( $\mathrm{E}_{\mathrm{SCE}}=$ $0.234 \mathrm{~V} / \mathrm{ENH}$ ), respectively. The operating voltage was controlled between $-0.9 \mathrm{~V}$ and $1.9 \mathrm{~V}$ at $20 \mathrm{mV} / \mathrm{s}$ in lithium based electrolyte, namely $0.3 \mathrm{M}$ lithium bistrifluoromethanesulfonimide (LiTFSI, Solvionic, purity $>99.99 \%)$ in 1-butyl-3-methylimidazoliumbis(trifluoromethanesulfonyl)-imide (BMITFSI). All the electrochemical measurements were performed at room temperature. The diffuse reflectance of $\mathrm{V}_{2} \mathrm{O}_{5}$ films were measured using a Varian Cary 5000 UV-VisNIR spectrophotometer. The diffuse reflectance was $e x$ situ recorded after application of various potentials.

\section{II.3. Thermochromic measurements on $\mathrm{VO}_{2}$ powders}

Electrical properties were performed with a four probes device on $\mathrm{VO}_{2}$ pellets obtained by uniaxial pressure at room-temperature on monoclinic $\mathrm{VO}_{2}$ powder sets. Thanks to home-built apparatus with a sample chamber coupled with a furnace and a nitrogen cryostat, the temperature was applied in the range $-20^{\circ} \mathrm{C}$ and $+100{ }^{\circ} \mathrm{C}$ with a slow rate of about $1{ }^{\circ} \mathrm{C} / \mathrm{min}$.

Optical properties of $\mathrm{VO}_{2}$ powder were tested versus temperature (in situ measurements in both heating and cooling modes) using a Varian Cary 5000 UV-Vis-NIR spectrophotometer. A home-built thermo-regulator has allowed varying the temperature within the range $5{ }^{\circ} \mathrm{C}$ $100{ }^{\circ} \mathrm{C}$ with $1{ }^{\circ} \mathrm{C}$ about of accuracy. Reflectance spectra of $\mathrm{VO}_{2}$ powder versus temperature were measured on a powder mixture with about $5 \mathrm{wt} \%$ of the $\mathrm{VO}_{2}$ sample and $95 \mathrm{wt} \%$ of $\mathrm{BaCO}_{3}$, the two powders being mixed homogeneously in an agate mortar before measurements.

For our powder mixture, made by mixing a high quantity of $\mathrm{BaCO}_{3}$ and a small proportion of $\mathrm{VO}_{2}$, the reflectance law of the mixture is quite complex, but can be approximated by the Duncan law 59, 60:

$$
\mathrm{K}_{\text {(mixture) }} / \mathrm{S}_{\text {(mixture) }}=\Sigma \mathrm{C}_{\mathrm{i}} \mathrm{K}_{\mathrm{i}} / \Sigma \mathrm{C}_{\mathrm{i}} \mathrm{Si}
$$

$=\left[\mathrm{C}_{\mathrm{VO}_{2}} \mathrm{~K}_{\mathrm{VO}_{2}}+\left(\mathrm{1}-\mathrm{C}_{\mathrm{VO}_{2}}\right) \cdot \mathrm{K}_{\mathrm{BaCO}_{3}}\right] /\left[\mathrm{C}_{\mathrm{VO}_{2}} \mathrm{~S}_{\mathrm{VO}_{2}}+\left(\mathrm{1}-\mathrm{C}_{\mathrm{VO}_{2}}\right) \cdot \mathrm{S}_{\mathrm{BaCO}_{3}}\right]$,

with $\mathrm{K}_{\text {(mixture), }} \mathrm{K}_{\mathrm{VO}_{2}}, \mathrm{~K}_{\mathrm{BaCO}_{3}}$ are the extinction coefficients of the mixture, the vanadium dioxide and the barium carbonate, respectively; $\mathrm{S}_{\text {(mixture), }} \mathrm{S}_{\mathrm{VO}_{2}}, \mathrm{~S}_{\mathrm{BaCO}_{3}}$ are the scattering coefficients of the mixture, the vanadium dioxide and the barium carbonate, respectively; with $\mathrm{C}_{\mathrm{VO}_{2}}$, the weight proportion of the vanadium dioxide inside the mixture. This law considering the extinction coefficient of the barium carbonate is negligible becomes:

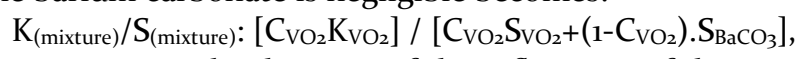

Hence, the decrease of the reflectivity of the powder mixture is inversely proportional to the extinction coefficient of the $\mathrm{VO}_{2}$ powder since, the Kubelka-Munk (basing on 2-flux approximation) relation linking the percentage of diffuse reflectance and the $(\mathrm{K} / \mathrm{S})$ ratio is : $\mathrm{K} / \mathrm{S}=(1-\mathrm{R})^{2} / 2 \mathrm{R}$.

The two half transition temperatures corresponding to the heating mode and the cooling mode, are named $\mathrm{T}^{1 / 2}$ up and $\mathrm{T}^{1 / 2}$ down, respectively

II. 4. Magnetic measurements on $\mathrm{V}_{2} \mathrm{O}_{3}$ powders

Magnetic measurements of $\mathrm{V}_{2} \mathrm{O}_{3}$ were performed in a MPMS-5S SQUID apparatus (Superconducting Quantum Interference Device) in DC measurement mode with an applied field equal to $2 \mathrm{~T}$ and with temperature ranging from 10 up to $300 \mathrm{~K}$.

\section{Results and discussion}

III.1. Single batch synthesis for the three oxides: $\mathrm{V}_{2} \mathrm{O}_{5}$, $\mathrm{VO}_{2}$ and $\mathrm{V}_{2} \mathrm{O}_{3}$

The first study concerns the structural characterization (using X-ray powder diffraction technique) of the vanadylglycolate (VEG) obtained by polyol precipitation process and the various $\mathrm{VO}_{\mathrm{x}}$ oxides synthesized after annealing at $500{ }^{\circ} \mathrm{C}$ under different atmospheres of the VEG precursor (Figure 2). 


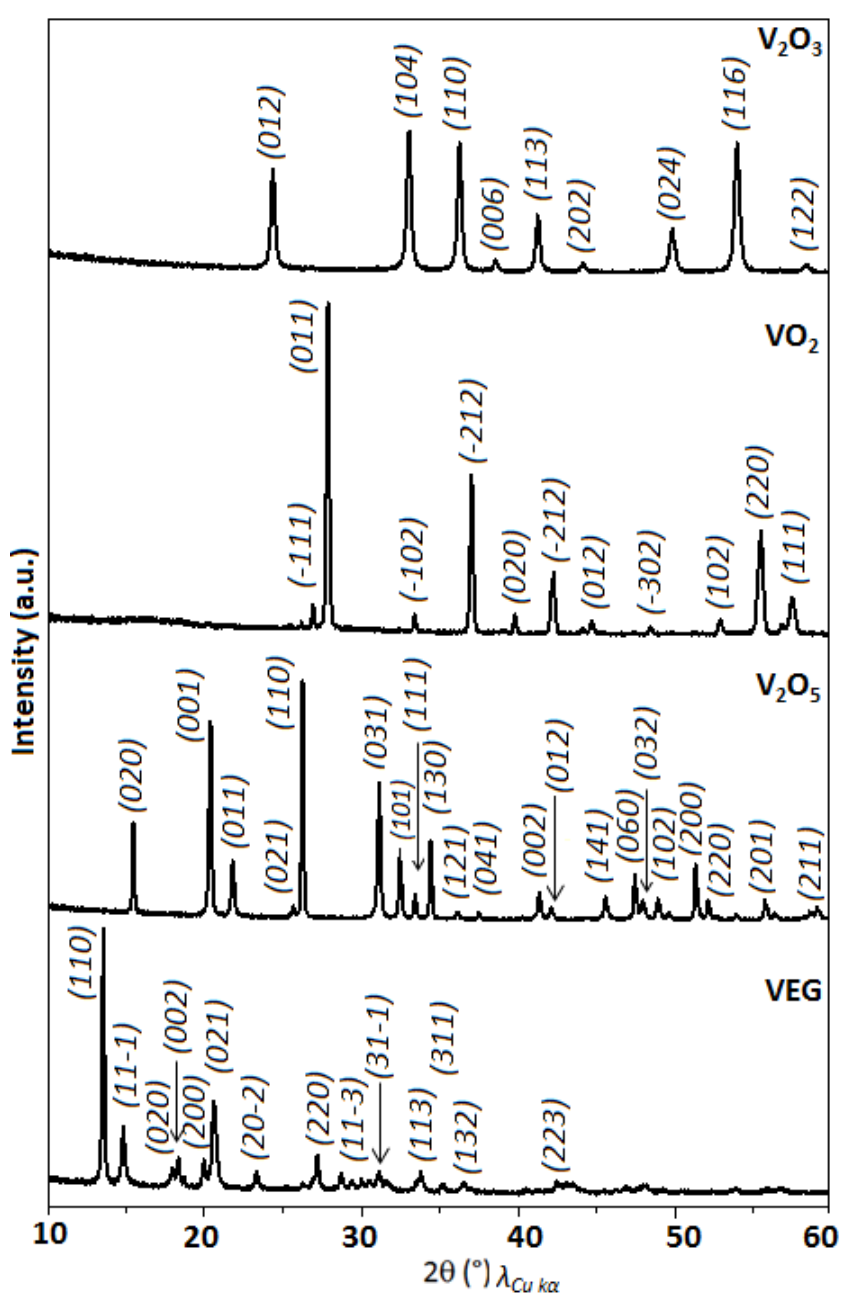

FIGURE 2. X-ray diffraction patterns of the as-synthesized VEG powders and the vanadium pentoxide, $\mathrm{V}_{2} \mathrm{O}_{5}$ vanadium dioxide $\mathrm{VO}_{2}$ and vanadium sesquioxide $\mathrm{V}_{2} \mathrm{O}_{3}$ obtained at 500 ${ }^{\circ} \mathrm{C}$ post-treatment under air, post-treatment under vacuum and $\mathrm{Ar}-\mathrm{H} 2$ atmosphere, respectively.

For the raw salt precursor (VEG), all the peaks of the corresponding X-ray diffraction pattern can be indexed in the VEG phase (oo-049-2497 JCPDS data file; C2/c space group). The post-thermal treatments at $500{ }^{\circ} \mathrm{C}$ under air, primary vacuum or $\mathrm{Ar} / \mathrm{H}_{2}$ (95/5 mol\%) atmosphere leads to pure phases in each case which respectively to the treatments are $\mathrm{V}_{2} \mathrm{O}_{5}$ (vanadium pentoxide) (oo-041-1426 JCPDS data file; Pmmn orthorhombic space group), monoclinic form (low temperature form) of $\mathrm{VO}_{2}$ (vanadium dioxide) (oo-043-1051 JCPDS data file; $C_{2} / m$ space group) and $\mathrm{V}_{2} \mathrm{O}_{3}$ (vanadium sesquioxide) (oo-034-0187 JCPDS data file; $R-3 C$ space group). All the isolated phases are well-crystallized; nevertheless, despite the same temperature and dwell time used for the annealing, the peak widths vary with the vanadium oxidation state. It increases as the valence state decreases. The peaks width are roughly with the same full width for $\mathrm{V}_{2} \mathrm{O}_{5}$ and $\mathrm{VO}_{2}$ but are significantly larger for $\mathrm{V}_{2} \mathrm{O}_{3}$.

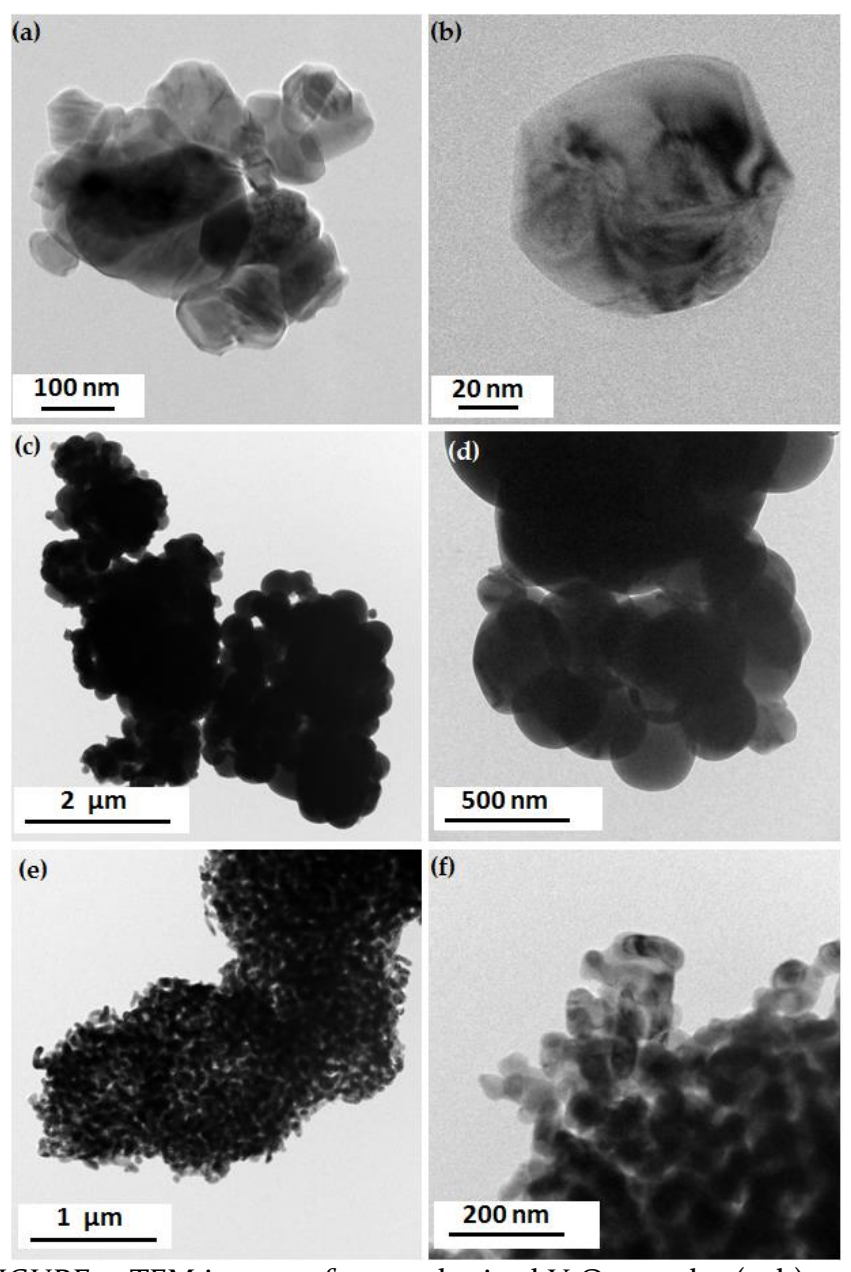

FIGURE 3. TEM images of as-synthesized $\mathrm{V}_{2} \mathrm{O}_{5}$ powder $(\mathrm{a}, \mathrm{b})$, $\mathrm{VO}_{2}$ powder (c, d) and $\mathrm{V}_{2} \mathrm{O}_{3}(\mathrm{e}, \mathrm{f})$ powder.

TEM microphotographs recorded on the three vanadium oxides issued from the various heat-treatments allow the comparison of the crystallite sizes (Figure 3).

In each case, i.e. for each vanadium oxide, even if the oxide crystallites tend to form large agglomerates, TEM preparation has allowed a sufficient dis-agglomeration to clearly distinguish the crystallites from each other. The three oxides exhibit quite isotropic crystallite shape. In good agreement to the diffraction peak widths, the $\mathrm{V}_{2} \mathrm{O}_{5}$ and $\mathrm{VO}_{2}$ crystallites show the largest diameter whereas the $\mathrm{V}_{2} \mathrm{O}_{3}$ crystallites are the smallest ones. Average crystallite diameter can be roughly estimated to $\approx 50-100 \mathrm{~nm}$ for $\mathrm{V}_{2} \mathrm{O}_{5}$ and $\mathrm{VO}_{2}$ (but with large diameter dispersion in both cases) and about $30 \mathrm{~nm}$ for $\mathrm{V}_{2} \mathrm{O}_{3}$ (but, this time, with a narrow particle diameter distribution).

Hence, polyol synthesis has allowed the use of the oxidation number versatility of the vanadium ion, to produce easily at moderate temperature ("chimie douce"), using a one-batch synthesis, the three most studied vanadium oxides, just varying the heat treatment atmosphere of the precipitated precursor. 
III.2. $\mathrm{V}_{2} \mathrm{O}_{5}$ compound: electrochromic properties.

$\mathrm{V}_{2} \mathrm{O}_{5}$, as a result of annealing in air was the easiest oxide to synthesize (i.e; the most stable).
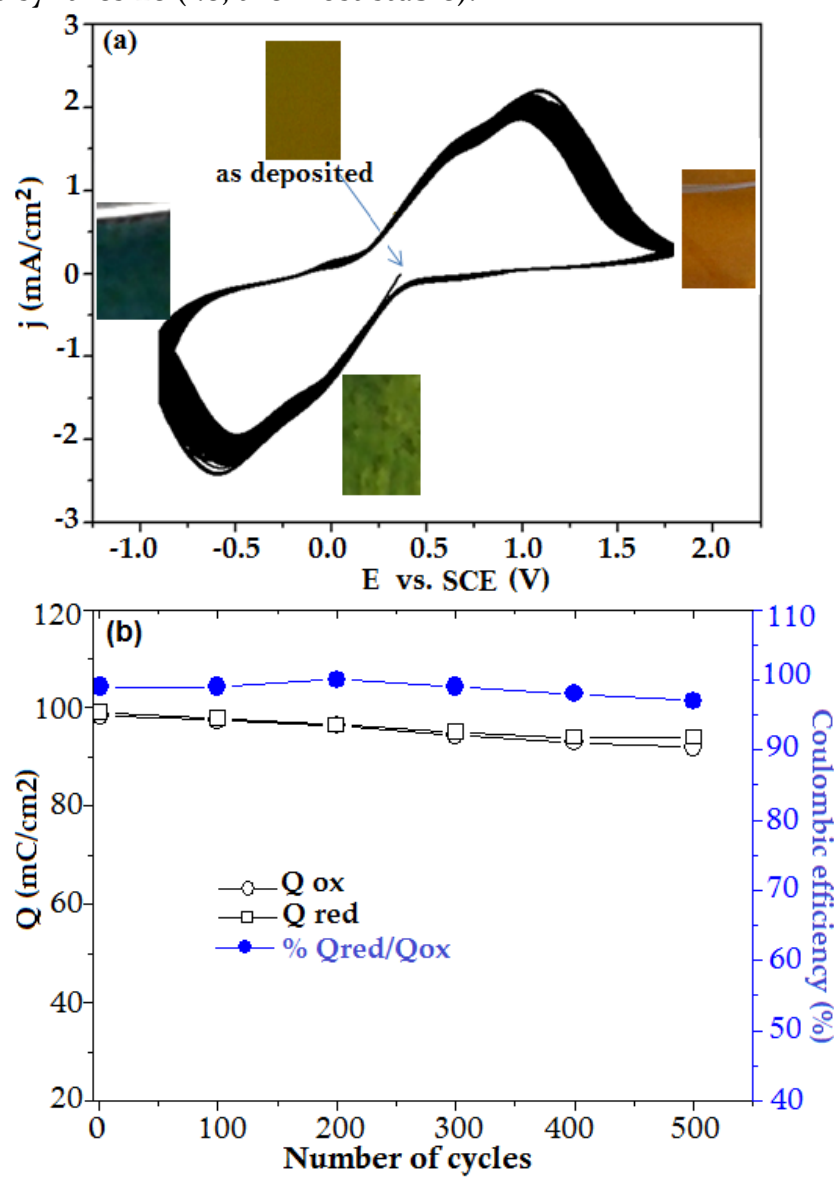

FIGURE 4. Cyclic voltammograms for $\mathrm{V}_{2} \mathrm{O}_{5}$ film cycled in $\mathrm{Pt} / 0.3 \mathrm{M} \mathrm{LiTFSI} / \mathrm{BMITFSI} / \mathrm{V}_{2} \mathrm{O}_{5}$ vs SCE with a $20 \mathrm{mV} / \mathrm{s}$ scan rate (a), the charge capacity evolution with the number of cycles is presented in (b) together with the Coulombic efficiency.

The cyclic voltammogramms, CVs, of $\mathrm{V}_{2} \mathrm{O}_{5} / \mathrm{o,3} \mathrm{M}$ LiTFSI, BMITFSI/Pt vs SCE in between - $0.9 \mathrm{~V}$ and $1.9 \mathrm{~V}$, at a cycling rate of $20 \mathrm{mV} / \mathrm{s}$, are shown in Figure 4a together with the corresponding color recorded, in the asdeposited state and at $1.9 \mathrm{~V},-0.3 \mathrm{~V}$ and $-0.9 \mathrm{~V}$. The evolutions of the capacity both in oxidation and reduction show a reversible phenomenon (Figure $\mathbf{4 b}$ ) illustrated by a coulombic efficiency defined as the $\mathrm{Q}_{\text {red }} / \mathrm{Q}_{\mathrm{ox}}$ ratio close to $100 \%$, and a nice cyclability up to 300 cycles. Upon cycling, the initial orange $\mathrm{V}_{2} \mathrm{O}_{5}$ turns into green and from green to blue.

Figure $\mathbf{5}$ reports the ex-situ recorded reflectance spectra at $1.9 \mathrm{~V}$ (Orange color), as deposited (orange-yellowish-), -0.3 V (Green) and -0.9 V (Blue).

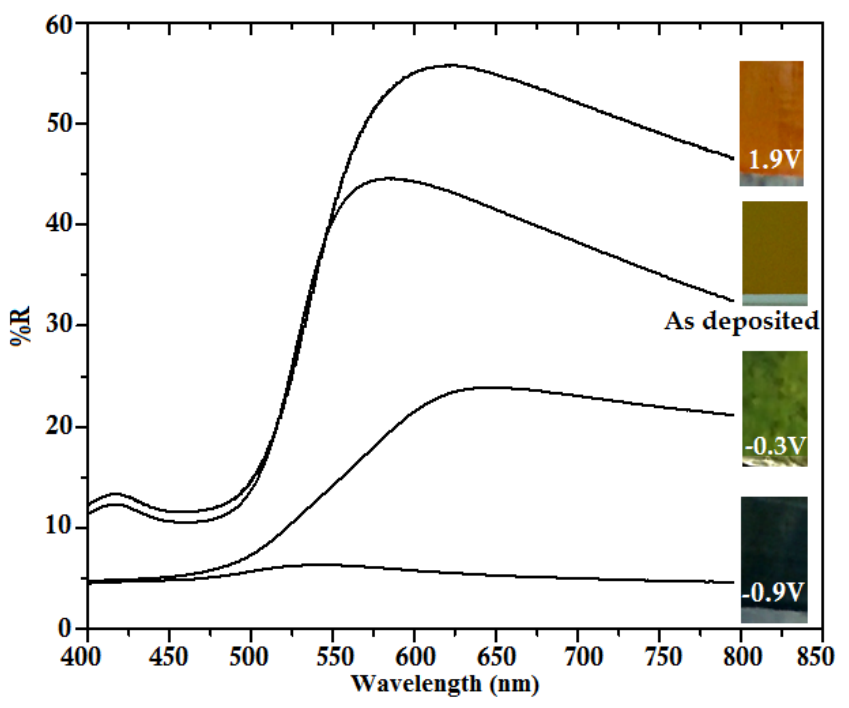

FIGURE 5. Diffuse reflectance of $\mathrm{V}_{2} \mathrm{O}_{5}$ films in the asdeposited state, oxidized state $(+1.9 \mathrm{~V})$ and two distinct reduced states (-0.3 and -0.9 V). Visual appearance, orange (1.9 $\mathrm{V})$, as-deposited (orange-yellowish).

The reversible color changes of $\mathrm{V}_{2} \mathrm{O}_{5}$ films in-between a reduced blue state $(-0.9 \mathrm{~V})$ and an oxidized-orange state $(+1.9 \mathrm{~V})$ are associated with reflectance values of about $5 \%$ and $56 \%$ at $630 \mathrm{~nm}$, respectively, leading to an optical reflectance modulation, $\Delta \mathrm{R}$, of about $51 \%$. The multi-color mechanism of $\mathrm{V}_{2} \mathrm{O}_{5}$ involves a reversible lithium intercalation/deintercalation represented by the following equation: $\mathrm{V}_{2} \mathrm{O}_{5}$ (orange) $+\mathrm{xLi}^{+}+\mathrm{xe} \rightleftharpoons \mathrm{Li}_{\mathrm{x}} \mathrm{V}_{2} \mathrm{O}_{5}$ (green-bluish)

This two steps electrochromism: orange to green and green to blue during the reduction was previously observed by several authors ${ }^{61}$, and was associated to the $\mathrm{V}^{++} / \mathrm{V}^{+}$redox couple, the green intermediate coloration being then explained by a potential range where the vanadium ions with the two oxidation numbers coexist. $\mathrm{Z}$. Tong et al recently ascribed the color change to olive color to the presence of $\mathrm{V}^{3+}$ ions associating the multicolor in $\mathrm{V}_{2} \mathrm{O}_{5}$ to the presence of $\mathrm{V}^{+} / \mathrm{V}^{++}$and $\mathrm{V}^{++}{ }^{22}, 29-31$. Such observation well agrees with the color of $\mathrm{V}^{3^{+}}, \mathrm{V}^{4+}$ and $\mathrm{V}^{5^{+}}$in aqueous solutions, i.e; in an octahedral ligand field with aqua ligands. In the mean time, current investigations in our group on $\mathrm{V}_{2} \mathrm{O}_{5}$ thin films grown by RF sputtering confirm a similar orange to green and green to blue color changes upon cycling while only $1.5 \mathrm{Li}$ are being exchanged. In addition, similar multi-color electrochromism has been detected on amorphous $\mathrm{VO}_{\mathrm{x}}$ films, with $\mathrm{x}$ in between 1.5 to 2. Further characterizations including XPS analysis upon cycling are in progress and will be reported in a forth coming paper as the understanding of the origin of the multicolor electrochromism of $\mathrm{V}_{2} \mathrm{O}_{5}$ is beyond the scope of this article.

III.3. $\mathrm{VO}_{2}$ compound: thermochromic properties

The first-order transition between monoclinic-form and rutile form of the vanadium dioxide being marked by an abrupt change of conductivity and a significant change of the optical properties, the $\mathrm{VO}_{2}$ powder was characterized, in situ versus temperature, by four-probe conductivity measurements and by diffuse reflectance. 
In the Figure 6, the evolution of the conductivity $(\log \sigma)$ versus $1000 / \mathrm{T}^{\circ}$ clearly shows a hysteresis loop characteristic of a metal-insulator transition. The conductivity drastically increases while the temperature decreases, with 3 orders of magnitude between the conductivity values at low and high temperatures, respectively. The hysteresis width, due to the energetic barrier to cross at the firstorder phase transition, is known to be depending on the crystallite size, impurities occurrence, etc ${ }^{62,}{ }^{63}$ but also on the kinetic of the measurements versus temperature. Herein, the transition temperature on the heating mode is $70^{\circ} \mathrm{C}\left(\mathrm{T}^{1 / 2} \mathrm{up}\right)$, the temperature on the cooling mode is $57^{\circ} \mathrm{C}$ ( $\mathrm{T}^{1 / 2}$ down). Moreover, it can be noted that the dependency of the $\log \sigma$ versus $1000 / \mathrm{T}^{\circ}$ is a linearly decreasing slope at low temperature as predicted for an insulator (or semi-conducting systems). However, similar linear decrease is observed at high temperature, in opposition with the predictable behavior for a metallic conduction. Nevertheless, the conductivity at elevated temperatures may be limited by the grain boundaries conductivity or even the probe-pellets connections.

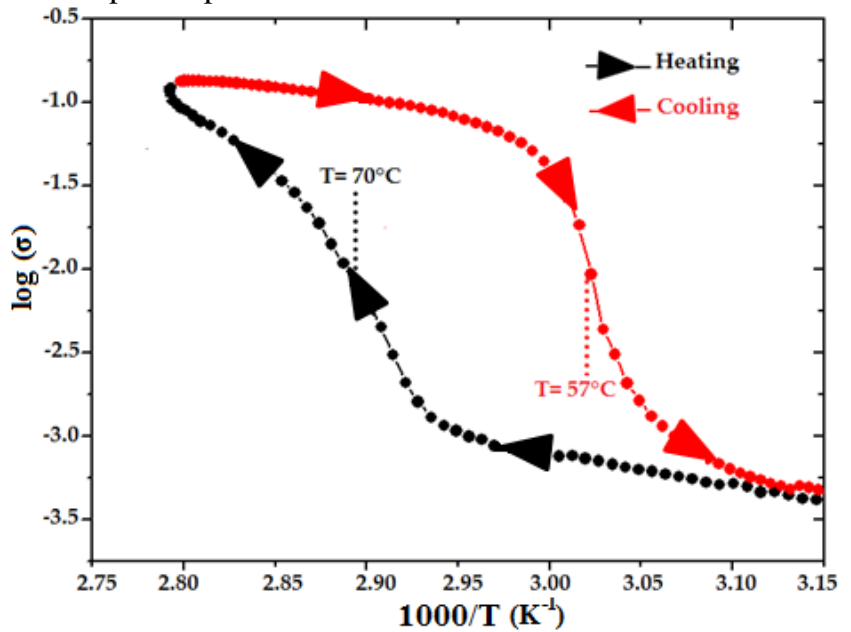

FIGURE 6. Evolution of the electrical conductivity of pellets constituted of $\mathrm{VO}_{2}$ nano-spherical particles vs 10oo/T. The transition temperatures on heating and cooling are indicated.

In the Figure 7, the evolution of the diffuse reflection of $\mathrm{VO}_{2}$ powder versus temperature at $2.3 \mu \mathrm{m}$ also shows a hysteresis loop marking the metal-insulator phase transition. The results are in good agreement with the ones observed by conductivity measurements despite the firstorder transitions temperatures are slightly divergent: the transition temperature on the heating mode is $72{ }^{\circ} \mathrm{C}\left(\mathrm{T}^{1} / 2\right.$ up), the temperature on the cooling mode is $36{ }^{\circ} \mathrm{C}\left(\mathrm{T}^{1} / 2\right.$ down). These temperatures divergences can be correlated to a slightly higher cooling and heating speed. Despite some controversies, in NIR range, the metallic state of the $\mathrm{VO}_{2}$ powder (rutile form) is known to exhibit a higher extinction coefficient than the insulator state (monoclinic phase) (i.e. the imaginary part of the complex index of refraction, $\boldsymbol{k}$ ). Our results confirm this higher extinction coefficient for the metallic-state powder than for the insulator-state powder; the significant variation allowing the characterization of the phase transition parameters via optical properties measurements versus temperature.

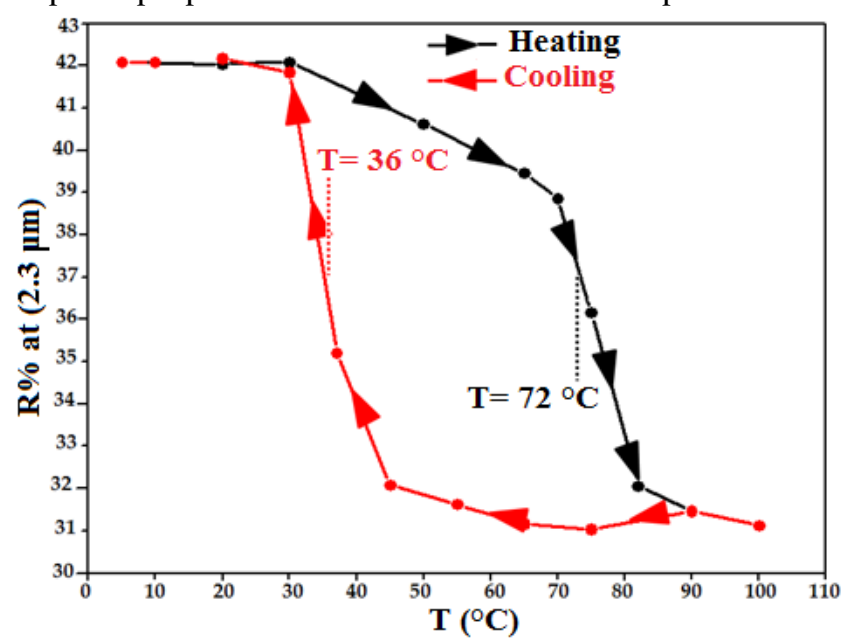

FIGURE 7. Diffuse reflectance of the $\mathrm{VO}_{2}-\mathrm{BaCO}_{3}$ powder mixture at $2300 \mathrm{~nm}$ wavelength as a function of the temperature. The transition temperatures on heating and cooling are indicated.

III.4. $\mathrm{V}_{2} \mathrm{O}_{3}$ compound: magnetic properties

Aiming at investigating the influence of the crystallite size on the magnetic properties of $\mathrm{V}_{2} \mathrm{O}_{3}$ oxides, a part of the $500{ }^{\circ} \mathrm{C}$ annealed $\mathrm{V}_{2} \mathrm{O}_{3}$ was post-annealed at higher temperature $\left(1000{ }^{\circ} \mathrm{C}\right)$ under same atmosphere $\left(\mathrm{Ar} / \mathrm{H}_{2}\right)$. The two diffractogramms are compared in the Figure 8.

Pure sesquioxide phase is obtained in two cases with, obviously, narrower peaks for the $1000{ }^{\circ} \mathrm{C}$ than for the 500 ${ }^{\circ} \mathrm{C}$-annealed oxides. The crystallite size, calculated from Debye-Scherrer calculations, increases from $30 \mathrm{~nm}$ for the $500{ }^{\circ} \mathrm{C}$-annealed compound to $75 \mathrm{~nm}$ for the $1000{ }^{\circ} \mathrm{C}$ annealed one ; hereafter, even if it represents a very rough designation, these two samples are called "nanometric" and "sub-micronic" $\mathrm{V}_{2} \mathrm{O}_{3}$. 


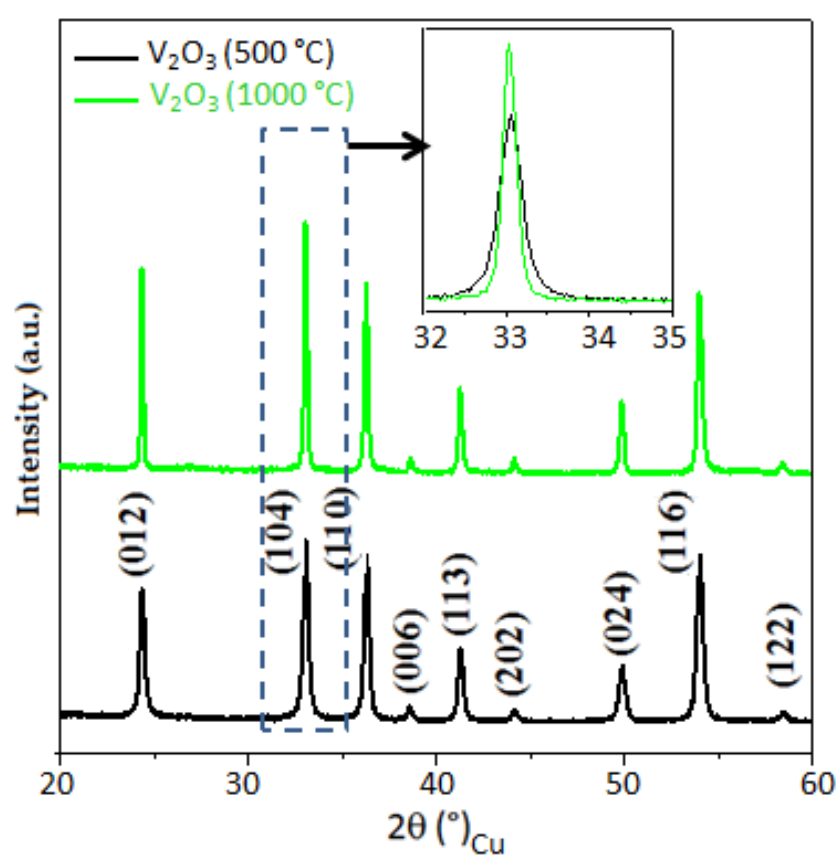

FIGURE 8. Comparison of the X-ray diffraction patterns of the vanadium sesquioxide, $\mathrm{V}_{2} \mathrm{O}_{3}$, synthesized at $500{ }^{\circ} \mathrm{C}$ under vacuum under $\mathrm{Ar}(95 \%)-\mathrm{H}_{2}$ (5\%) atmosphere (Black color) and after an additional annealing at $1000{ }^{\circ} \mathrm{C}$ under same atmosphere (Green color).

The temperature variation of the magnetic susceptibility $\mathrm{M}^{-1}$ (for $\mathrm{H}=2.0 \mathrm{~T}$ ) for the $\mathrm{V}_{2} \mathrm{O}_{3}$ powders obtained after the annealing treatments at $500{ }^{\circ} \mathrm{C}$ and $1000{ }^{\circ} \mathrm{C}$, is plotted in Figure 9, in both ZFC (zero field cooled) as well as FC (field cooled) cases. At first sights, both evolutions follow a similar trend with three definite steps: linear variations of $\mathrm{M}^{-1}$ at high temperature and very low temperature separated by brutal drop of susceptibility at intermediate temperature. This result is in good agreement with the reported literature ${ }^{46}$. The magnetic susceptibility was found to linearly increase from $300 \mathrm{~K}$ to about $150 \mathrm{~K}$ as in a standard paramagnetic domain. An anomalous drop in magnetic susceptibility showing a paramagnetic to antiferromagnetic transition is observed at about $100 \mathrm{~K}$. The magnetic susceptibility subsequently increases again at lower temperatures. Above $200 \mathrm{~K}$ the magnetic susceptibility data was fitted using the Curie-Weiss law: $\mathrm{M} / \mathrm{H}=$ $\mathrm{C} /(\mathrm{T}-\theta)$. The Curie constant yields an effective paramagnetic moment per $\mathrm{V}$ atom, $\mu_{\mathrm{eff}}=\mathbf{2 . 5 4} \mu \mathrm{B}$ and $\mu_{\mathrm{eff}}=\mathbf{2 . 1 7} \mu \mathrm{B}$ for the $500{ }^{\circ} \mathrm{C}$ - and the $1000{ }^{\circ} \mathrm{C}$ annealed compound, respectively. These values are close to the Hund's rule value for $\mathrm{V}^{3+}$, namely $\mu_{\mathrm{eff}}=\mathbf{2 . 8} \mu \mathrm{B}$. So, above the transition temperature, where antiferromagnetic order sets in, all V moments seem paramagnetic. Nevertheless, experimental values are in both cases slightly lower than the theoretical one, especially for the $1000{ }^{\circ} \mathrm{C}$ annealed compound. Furthermore, the calculated paramagnetic Curie temperature: $\theta$, is about $\theta=-950 \mathrm{~K}$ and $-530 \mathrm{~K}$, for the $500{ }^{\circ} \mathrm{C}$ - and the $1000{ }^{\circ} \mathrm{C}$ annealed compound, respectively. The strongly negative values of $\theta$ also indicate that the $\mathrm{V}$ moments are antiferromagnetically coupled. The number of defects, as herein $\mathrm{V}^{5+}$ or $\mathrm{V}^{4+}$ ions caused by over-oxygen stoichi- ometry or sub cationic stoichiometry, are known to be limited by downsizing a crystal to the nanoscale. This can explain why the effective paramagnetic moment is closer to the theoretical value for the $500{ }^{\circ} \mathrm{C}$-annealed compound than for the $1000{ }^{\circ} \mathrm{C}$-annealed compound. Furthermore, the $\mathrm{V}^{5^{+}}$or $\mathrm{V}^{4+}$ defects seem also to be at the origin of a decrease of the antiferromagnetic coupling field between the $\mathrm{V}^{3+}$ moments. Consequently, it is logical to observe for the ZFC signal, a paramagnetic to antiferromagnetic transition at higher temperature for the nanometric $\mathrm{V}_{2} \mathrm{O}_{3}\left(-108{ }^{\circ} \mathrm{C}\right)$ than for the sub-micronic $-\mathrm{V}_{2} \mathrm{O}_{3}(-$ $\left.132^{\circ} \mathrm{C}\right)$.
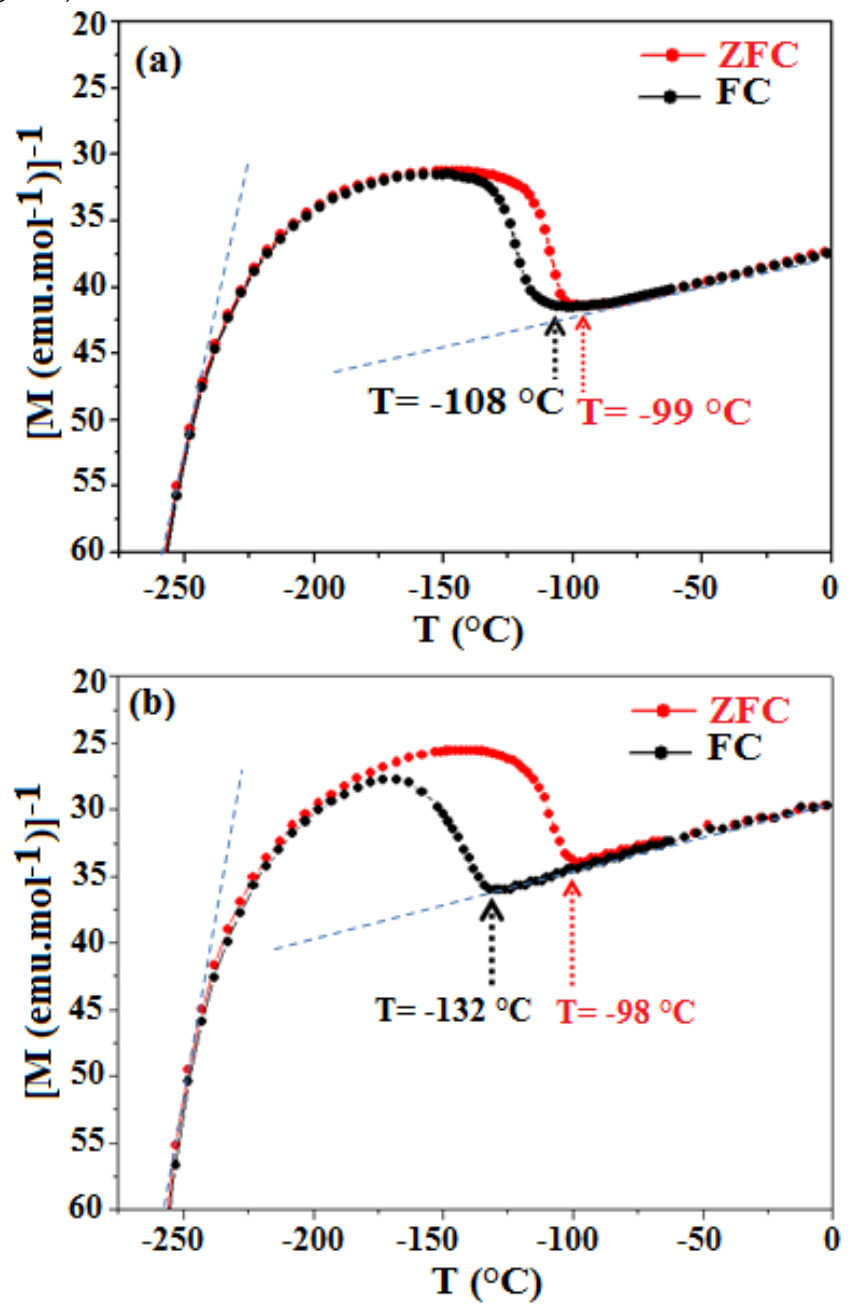

FIGURE 9. (DC magnetization, $\mathrm{M}$ )-1 measured at $\mathrm{H}=2.0 \mathrm{~T}$ vs temperature in FC and ZFC modes on the $500{ }^{\circ} \mathrm{C}$-annealed $\mathrm{V}_{2} \mathrm{O}_{3}$ sample (a) and the $1000{ }^{\circ} \mathrm{C}$-annealed $\mathrm{V}_{2} \mathrm{O}_{3}$ sample (b). The linear regions (dash blue) are evidenced above $150 \mathrm{~K}$ and below $50 \mathrm{~K}$.

Similarly, the hysteresis is larger for the sub-micronic sample than for the nano one since the antiferromagnetic to paramagnetic transition is shown to be nearly the same for both compounds $\left(-99{ }^{\circ} \mathrm{C}\right.$ and $-98{ }^{\circ} \mathrm{C}$ for respectively the $500{ }^{\circ} \mathrm{C}$ and the $1000{ }^{\circ} \mathrm{C}$-annealed sample). It can be supposed that the observation of a transition in the FC signal similar for both samples is due to two negatively superimposed effects: the sub-micronic sample exhibit 
stoichiometric defects tending to stabilize paramagnetic domain but at the same time, the antiferromagnetic domain could be more expended due to less surface effect, and so, more robust to the elevation of temperature. It can be noticed that the oxygen stoichiometry was already reported to significantly change the $\mathrm{V}_{2} \mathrm{O}_{3}$ phase transition behavior ${ }^{64}$. Finally, a second region of Curie-Weiss behavior is observed at low temperatures. The magnetic measurements show for both samples linearity in $\mathrm{M}$ vs. $\mathrm{H}$ behavior below $10 \mathrm{~K}$ (Blue dash line below $240^{\circ} \mathrm{C}$ in Fig. 9), as expected for the paramagnetic Brillouin function. Previous researchers ${ }^{65}$ have suggested that the surface spins in antiferromagnetic nanoparticles are uncompensated, and may produce a paramagnetic susceptibility below the overall Neel temperature, just as observed on the $\mathrm{V}_{2} \mathrm{O}_{3}$ powders, herein. The fitted Curie-Weiss law results in a significantly smaller Curie constant than the one found at high temperatures leading for the effective paramagnetic moments to values equal to 0.78 and 0.66 $\mu \mathrm{B}$ for respectively the $500{ }^{\circ} \mathrm{C}$-annealed and the $1000{ }^{\circ} \mathrm{C}$ annealed compound. The curie temperatures are for both cases negligible (about oK) what show a pure paramagnetic behavior for this low temperature branches. The small moment is due to the fact that for both samples only a subset of the $\mathrm{V}$ atoms, corresponding to the surface atoms, remains paramagnetic at low temperature. Interestingly, from these considerations, the surface / volume ratio is higher for the smaller crystallites leading to an effective moment slightly higher for the $500{ }^{\circ} \mathrm{C}$-annealed compounds than for the $1000{ }^{\circ} \mathrm{C}$-annealed sample. Hence, in good agreement with previous results shown in literature ${ }^{42}$, it can be suggested that the magnetization data shown of $\mathrm{V}_{2} \mathrm{O}_{3}$ powder represent the sum of the contributions both from the surface and the core spins. By contrast, below the transition temperature, the interior of the nanoparticle is antiferromagnetic, while the spins on the surface are either free or paramagnetic. When the temperature is low enough, these surface spin contributions dominate, and this situation leads to the observed increase in susceptibility at low temperatures.

\section{Conclusion}

In this paper, we successfully demonstrate the control of the valence states in $\mathrm{VO}_{\mathrm{x}}$ oxides using a low cost synthesis route based on the annealing of a single vanadylglycolate (VEG) precursor. Well crystallized, $\mathbf{V}_{\mathbf{2}} \mathbf{O}_{3}, \mathbf{V O}_{\mathbf{2}}$ and $\mathbf{V}_{\mathbf{2}} \mathbf{O}_{5}$ are prepared after annealing of the VEG at $500{ }^{\circ} \mathrm{C}$, in a 95 $\% \mathrm{Ar} / 5 \% \mathrm{H}_{2}$ mixture, in vacuum $\left(\mathrm{PO}_{2} \approx 210^{5} \mathrm{~Pa}\right)$ and in air, respectively. The as prepared $\mathrm{V}_{2} \mathrm{O}_{3}, \mathrm{VO}_{2}$ and $\mathrm{V}_{2} \mathrm{O}_{5}$ powders, pure and well crystallized, are characterized on a structural, chemical, magnetic and optical point of view, coupling some adequate techniques among the large panels of the ones devoted to powders characterization.

As an illustration, the magnetic $\left(\mathrm{V}_{2} \mathrm{O}_{3}\right)$, thermochromic $\left(\mathrm{VO}_{2}\right)$ and electrochromic $\left(\mathrm{V}_{2} \mathrm{O}_{5}\right)$ behaviors of the asprepared powders were studied.

\section{AUTHOR INFORMATION}

\section{Corresponding Author}

* Aline Rougier.

aline.rougier@icmcb.cnrs.fr

\section{Author Contributions}

The manuscript was written through contributions of all authors.

\section{REFERENCES}

(1) Zheng, L.; Xu, Y.; Jin, D.; Xie, Y. Novel Metastable Hexagonal $\mathrm{MoO}_{3}$ Nanobelts: Synthesis, Photochromic, and Electrochromic Properties. Chem. Mater. 2009, 21, 56815690.

(2) Lu, M.; Shao, C.; Wang, K.; Lu, N.; Zhang, X.; Zhang, P.; Zhang, M.; Li, X.; Liu, Y. p- $-\mathrm{MoO}_{3}$ Nanostructures/n- $\mathrm{TiO}_{2}$ Nanofiber Heterojunctions: Controlled Fabrication and Enhanced Photocatalytic Properties. ACS Appl. Mater. Interfaces 2014, 6, 9004-9012.

(3) Yin, H.; Yu, K. ; Song, C. ; Huang, R.; Zhu, Z. Synthesis of Au-Decorated $\mathrm{V}_{2} \mathrm{O}_{5} @ \mathrm{ZnO}$ Heteronanostructures and Enhanced Plasmonic Photocatalytic Activity. ACS Appl. Mater. Interfaces 2014, 6, 14851-1486o.

(4) Sauvet, K.; Rougier, A.; Sauques, L. Electrochromic Electrochromic $\mathrm{WO}_{3}$ thin films active in the IR region. Sol. Energy Mater. Sol. Cells 2008, 92, 209-215.

(5) Li, L.; Steiner, U.; Mahajan, S.; Improved electrochromic performance in inverse opal vanadium oxide films. J. Mater. Chem., 2010, 20, 7131-7134.

(6) Dinh, N. N.; Quyen, N. M.; Chung, D. N.; Zikova, M.; Truong, V. V. Highly-efficient electrochromic performance of nanostructured $\mathrm{TiO}_{2}$ films made by doctor blade technique. Sol. Energy Mater. Sol. Cells 2011, 95,618-623.

(7) Yu, R.; Zhang, C.; Meng, Q.; Chen, Z.; Liu, H.; Guo, Z. Facile Synthesis of Hierarchical Networks Composed of Highly Interconnected $\mathrm{V}_{2} \mathrm{O}_{5}$ Nanosheets Assembled on Carbon Nanotubes and Their Superior Lithium Storage Properties. ACS Appl. Mater. Interfaces 2013, 5, 1239412399.

(8) Li, X. ; Liu, C. ; Zhang, C. ; Fu, H. ; Nan, X. ; Ma , W. ; Li, Z. ; Wang, K.; Wu, H.; Cao, G. Effects of Preinserted Na Ions on Li-Ion Electrochemical Intercalation Properties of $\mathrm{V}_{2} \mathrm{O}_{5}$. ACS Appl. Mater. Interfaces 2016, 8, 24629-24637.

(9) Tang, Y.; Rui, X.; Zhang, Y.; Lim, T. M.; Dong, Z.; Hng, H. H.; Chen, X, Yan, Q.; Chen, Z. Vanadium pentoxide cathode materials for high-performance lithium-ion batteries enabled by a hierarchical nanoflower structure via an electrochemical process. J. Mater. Chem. A, 2013, 1, 8288.

(10) Ren, X.; Zhai, Y.; Zhu, L.; He, Y.; Li, A.; Guo, C.; Xu, L. Fabrication of Various $\mathrm{V}_{2} \mathrm{O}_{5}$ Hollow Microspheres as Excellent Cathode for Lithium Storage and the Application in Full Cells. ACS Appl. Mater. Interfaces 2016, 8, 1720517211.

(11) Caes, S.; Arrebola, J. C.; Krins, N.; Eloy, P.; Gaigneaux, E. M.; Henrist, C.; Cloots, R.; Vertruyen, B. Mesoporous 
lithium vanadium oxide as a thin film electrode for lithium-ion batteries: comparison between direct synthesis of $\mathrm{LiV}_{2} \mathrm{O}_{5}$ and electrochemical lithium intercalation in $\mathrm{V}_{2} \mathrm{O}_{5}$. J. Mater. Chem. A, 2014, 2, 5809-5815.

(12) Mjejri, I.; Etteyeb, N.; Sediri, F. $\mathrm{H}_{2} \mathrm{~V}_{3} \mathrm{O}_{8}$ nanobelts as a novel stable electrode material with good reversibleredox performance. J. Alloys Compd. 2014, 611, 372-380.

(13) Tepavcevic S.; Xiong, H.; Stamenkovic, V. R.; Zuo, X.; Balasubramanian, M.; Prakapenka, V. B.; Johnson, C. S.; Rajh, T. Nanostructured Bilayered Vanadium Oxide Electrodes for Rechargeable Sodium-Ion Batteries. ACS Nano.; 2012, 6, 530-538.

(14) Zhang, L. L.; Liang, G.; Ignatov, A.; Croft, M. C.; Xiong, X. Q.; Hung, I. M.; Huang, Y. H.; Hu, X. L.; Zhang, W. X.; Peng, Y. L. Effect of Vanadium Incorporation on Electrochemical Performance of $\mathrm{LiFePO}_{4}$ for Lithium-Ion Batteries. J. Phys. Chem. C 2011, 115, 13520-13527.

(15) Simões, M.; Mettan, Y.; Pokrant, S.; Weidenkaff, A. Surface-Modified Lithiated $\mathrm{H}_{2} \mathrm{~V}_{3} \mathrm{O}_{8}$ : A Stable High Energy Density Cathode Material for Lithium-Ion Batteries with $\mathrm{LiPF}_{6}$ Electrolytes. J. Phys. Chem. C 2014, 118, 14169-14176.

(16) Yu, L.; Xi, J. Durable and Efficient PTFE Sandwiched SPEEK Membrane for Vanadium Flow Batteries. ACS Appl. Mater. Interfaces 2016, 8, 23425-23430.

(17) Iida, Y.; Kaneko, Y.; Kanno, Y. Fabrication of pulsedlaser deposited $\mathrm{V}_{2} \mathrm{O}_{5}$ thin films for electrochromic devices. J. Mater. Process. Technol. 2008, 197, 261-267.

(18) Kovendhan, M., Joseph, D. P., Manimuthu, P., Sendilkumar, A., Karthick, S.N.; Sambasivam, S.; Vijayarangamuthu, K.; Kim, H. J.; Choi, B. C.; Asokan, K.; Venkateswaran, C.; Mohan, R. Prototype electrochromic device and dye sensitized solar cell using spray deposited undoped and ' $\mathrm{Li}$ ' doped $\mathrm{V}_{2} \mathrm{O}_{5}$ thin film electrodes. Curr. App. Phys. 2015, 15, 622-631.

(19) Yang, Y.; Kim, D.; Schmuki, P. Electrochromic properties of anodically grown mixed $\mathrm{V}_{2} \mathrm{O}_{5}-\mathrm{TiO}_{2}$ nanotubes. Electrochem. Commun. 2011, 13, 1021-1025.

(20) Wei, Y.; Zhou, J.; Zheng, J.; Xu, C. Improved stability of electrochromic devices using Ti-doped $\mathrm{V}_{2} \mathrm{O}_{5}$ film. Electrochim. Acta 2015, 166, 277-284.

(21) Kang, W.; Yan, C.; Wang, X.; Foo, C. Y.; Tan, A. W. M.; Chee, K. J. Z.; Lee, P. S. Green synthesis of nanobeltmembrane hybrid structured vanadium oxide with high electrochromic contrast. J. Mater. Chem. C, 2014, 2, 47274732.

(22) Tong, Z.; Yang, H.; Na, L.; Qu, H.; Zhang, X.; Zhao, J.; $\mathrm{Li}, \mathrm{Y}$. Versatile displays based on a 3-dimensionally ordered macroporous vanadium oxide film for advanced electrochromic devices. J. Mater. Chem. C, 2015, 3, 31593166.

(23) Qiu, D. H.; Wen Q. Y.; Yang, Q. H.; Chen, Z.; Jing, Y. L.; Zhang, H. W. Electrically-driven metal-insulator transition of vanadium dioxide thin films in a metal-oxideinsulator-metal device structure. Mater. Sci. Semicond. Process. 2014, 27, 140-144.

(24) Seyfouri, M.M.; Binions, R. Sol-gel approaches to thermochromic vanadium dioxide coating for smart glaz- ing application. Sol. Energy Mater. Sol. Cells 2017, 59, 5265 .

(25) Li, W.; Ji, S.; Qian, K.; Jin, P. Preparation and characterization of $\mathrm{VO}_{2}(\mathrm{M})-\mathrm{SnO}_{2}$ thermochromic films for application as energy-saving smart coatings. J. Colloid Interface Sci. 2015, 456,166-173.

(26) Zhang, H.; Xiao, X.; Lu, X.; Chai, G.; Sun, Y.; Zhan, Y.; $\mathrm{Xu}, \mathrm{G}$. A cost-effective method to fabricate $\mathrm{VO}_{2}(\mathrm{M})$ nanoparticles and films with excellent thermochromic properties. J. Alloys Compd. 2015, 636, 106-112.

(27) Wu, C.; Feng, F.; Xie, Y. Design of vanadium oxide structures with controllable electrical properties for energy applications. Chem. Soc. Rev., 2013, 42, 5157-5183.

(28) Zhang, Z.; Gao, Y.; Chen, Z.; Du, J.; Cao, C.; Kang, L.; Luo, H. Thermochromic $\mathrm{VO}_{2}$ Thin Films: Solution-Based Processing, Improved Optical Properties, and Lowered Phase Transformation Temperature. Langmuir 2010, 26, 10738-10744.

(29) Tong, Z.; Zhang, X.; Lv, H.; Li, N.; Qu, H.; Zhao, J.; Li, Y.; Liu, X.Y. From Amorphous Macroporous Film to $3 \mathrm{D}$ Crystalline Nanorod Architecture: A New Approach to Obtain High-Performance $\mathrm{V}_{2} \mathrm{O}_{5}$ Electrochromism. Adv. Mater. Interfaces 2015, 2, 1500230.

(30) Tong, Z.; Lv, H.; Zhang, X.; Yang, H.; Tian, Y.; Li, N.; Zhao, J.; Li, Y. Novel morphology changes from $3 \mathrm{D}$ ordered macroporous structure to $\mathrm{V}_{2} \mathrm{O}_{5}$ nanofiber grassland and its application in electrochromism. Scientific Reports 5:16864.

(31) Tong, Z.; Hao, J.; Zhang, K.; Zhao, J.; Su, B. L.; Li, Y. Improved electrochromic performance and lithium diffusion coefficient in three-dimensionally ordered macroporous $\mathrm{V}_{2} \mathrm{O}_{5}$ films. J. Mater. Chem. C, 2014, 2, 36513658 .

(32) Quinzeni, I.; Ferrari S.; Quartarone, E.; Mustarelli, P. Structural, morphological and electrochemical properties of nanocrystalline $\mathrm{V}_{2} \mathrm{O}_{5}$ thin films deposited by means of radiofrequency magnetron sputtering. J. Power Sources 2011, 196 10228-10233.

(33) Mjejri, I.; Manceriu, L. M.; Gaudon, M.; Rougier, A.; Sediri, F. Nano-vanadium pentoxide films for electrochromic displays. Solid State Ionics 2016, 292, 8-14.

(34) Garcia-Lobato, M.A.; Martinez, A. I.; Perry, D. L.; Castro-Roman, M.; Zarate, R. A.; Escobar-Alarcon, L. Elucidation of the electrochromic mechanism of nanostructured iron oxides films. Sol. Energy Mater. Sol. Cells 2011, 95, 751-758.

(35) Bencic, S.; Orel, B.; Surca, A..; Lavrencic ${ }^{\vee}$ Stangar, U. structural and electrochromic properties of nanosized

$\mathrm{Fe} / \mathrm{V}$-oxide films with $\mathrm{FeVO}_{4}$ and $\mathrm{Fe}_{2} \mathrm{~V}_{4} \mathrm{O}_{13}$ grains:

comparative studies with crystalline $\mathrm{V}_{2} \mathrm{O}_{5}$. Solar Energy 2000, 68, 499-515.

(36) Rachel Malini, D.; Sanjeeviraja, C. $\mathrm{H}^{+}$-intercalation Electrochemical/Electrochromic Properties of V-Ce Mixed Oxide Thin Films. Int. J. Electrochem. Sci. 2013, 8, 1349-1365.

(37) Ma, X.; Lu, S.; Wan, F.; Hu, M.; Wang, Q.; Zhu, Q.; Zakharova, G. S. Synthesis and Electrochromic Characte- 
rization of Graphene $/ \mathrm{V}_{2} \mathrm{O}_{5} / \mathrm{MoO}_{3}$ Nanocomposite Films. ECS J. Solid State Sci. Technol. 2016, 5, 572-577.

(38) Dahlman, C. J.; LeBlanc, G.; Bergerud, A.; Staller, C.; Adair, J.; Milliron, D. J. Electrochemically Induced Transformations of Vanadium Dioxide Nanocrystals. Nano Lett. 2016, 16, 6021-6027.

(39) Ji, Y. X.; Niklasson, G. A.; Granqvist, C. G. Boman, M.; Thermochromic $\mathrm{VO}_{2}$ films by thermal oxidation of vanadium in $\mathrm{SO}_{2}$. Sol. Energy Mater. Sol. Cells 2016, 144 713716.

(40) Zhu, B.; Tao, H.; Zhao, X. Effect of buffer layer on thermochromic performances of $\mathrm{VO}_{2}$ films fabricated by magnetron sputtering. Infrared Phys. Technol. 2016, 75, 22-25.

(41) Popuri, S. R.; Miclau M.; Artemenko, A.; Labrugere, C.; Villesuzanne, A.; Pollet, M. Rapid Hydrothermal Synthesis of $\mathrm{VO}_{2}$ (B) and Its Conversion to Thermochromic $\mathrm{VO}_{2}(\mathrm{M} 1)$. Inorg. Chem. 2013, 52, 4780-4785.

(42) Parikh, P.; Chakraborty, C.; Abhilash, T. S.; Sengupta, S.; Cheng, C.; Wu, J.; Deshmukh, M. M. Dynamically Tracking the Strain Across the Metal-Insulator Transition in $\mathrm{VO}_{2}$ Measured Using Electromechanical Resonators. Nano Lett. 2013, 13, 4685-4689.

(43) Jung, H. M.; Um, S. Modification of electrical and surface properties of $\mathrm{V}_{2} \mathrm{O}_{3}$ multilayer films on resinimpregnated highly oriented pyrolytic graphite composite substrates by shrinkage stress relaxation with chemical additives. Thin Solid Films 2013, 548, 98-102.

(44) Metcalf, P. A.; Guha, S.; Gonzalez, L. P.; Barnes, J. O.; Slamovich, E. B.; Honig, J. M. Electrical, structural, and optical properties of $\mathrm{Cr}$-doped and non-stoichiometric $\mathrm{V}_{2} \mathrm{O}_{3}$ thin films. Thin Solid Films 2007, 515, 3421-3425.

(45) Jiang, H.; Jia, G.; Hu, Y.; Cheng, Q.; Fu, Y.; Li, C. Ultrafine $\mathrm{V}_{2} \mathrm{O}_{3}$ Nanowire Embedded in Carbon Hybrids with Enhanced Lithium Storage Capability. Ind. Eng. Chem. Res. 2015, 54, 2960-2965.

(46) Santulli, A. C.; Xu, W.; Parise, J. B.; Wu. L.; Aronson, M. C.; Zhang, F.; Nam, C. Y.; Black, C. T.; Tiano, A. L.; Wong, S. S. Synthesis and characterization of $\mathrm{V}_{2} \mathrm{O}_{3}$ nanorods. Phys. Chem. Chem. Phys., 2009, 11, 3718-3726.

(47) Desai, S. D.; Cussler, E. L. Microporous Vanadium Pentaoxide. 1. Vanadyl Isopropoxide in Microemulsions. Langmuir 1997, 13, 1496-1500.

(48) Shao, G. N.; Imran, S. M.; Jeon, S. J.; Kang, S. J.; Haider, S. M.; Kim, H. T. Sol-gel synthesis of vanadium doped titania: Effect of the synthetic routes and investigation of their photocatalytic properties in the presence of natural sunlight. Appl. Surf. Sci. 2015, 351, 1213-1223.

(49) Nguyen, T. D.; Trong, O. D. Solvo-Hydrothermal Approach for the Shape-Selective Synthesis of Vanadium Oxide Nanocrystals and Their Characterization. Langmuir 2009, 25, 5322-5332.

(50) Quinzeni, I.; Ferrari, S.; Quartarone, E.; Mustarelli, P. Structural, morphological and electrochemical properties of nanocrystalline $\mathrm{V}_{2} \mathrm{O}_{5}$ thin films deposited by means of radiofrequency magnetron sputtering. J. Power Sources 2011, 196, 10228-10233.
(51) Avellaneda, C. O. Electrochromic performance of solgel deposited $\mathrm{V}_{2} \mathrm{O}_{5}$ : Ta films. Mat. Sci. Eng. B 2007, 138, 118-122.

(52) Santos, R.; Loureiro, J.; Nogueira, A.; Elangovan, E.; Pinto, J. V.; Veiga, J. P.; Busani, T.; Fortunato, E.; Martins, R.; Ferreira, I. Thermoelectric properties of $\mathrm{V}_{2} \mathrm{O}_{5}$ thin films deposited by thermal evaporation. App. Surf. Sci. 2013, 282, 590-594.

(53) Danine, A.; Cojocaru, L.; Faure, C.; Olivier, C.; Toupance, T.; Campet, G.; Rougier, A. Room Temperature UV treated $\mathrm{WO}_{3}$ thin films for electrochromic devices on paper substrate. Electrochimica Acta 2014, 129, 113-119.

(54) Fan, L. L.; Chen, S.; Luo, Z. L.; Liu, Q. H.; Wu, Y. F.; Song, L.; Ji, D. X.; Wang, P.; Chu, W. S.; Gao, C.; Zou, C. W.; Wu, Z. Y. Strain Dynamics of Ultrathin $\mathrm{VO}_{2}$ Film Grown on $\mathrm{TiO}_{2}$ (oo1) and the Associated Phase Transition Modulation. Nano Lett. 2014, 14, 4036-4043.

(55) Kang, L.; Gao, Y.; Luo, H.; Chen, Z.; Du, J.; Zhang, Z. Nanoporous Thermochromic $\mathrm{VO}_{2}$ Films with Low Optical Constants, Enhanced Luminous Transmittance and Thermochromic Properties. ACS Appl. Mater. Interfaces 2011, 3, 135-138.

(56) Ragupathy, P.; Shivakumara, S.; Vasan, H. N.; Munichandraiah, N. Preparation of Nanostrip $\mathrm{V}_{2} \mathrm{O}_{5}$ by the Polyol Method and Its Electrochemical Characterization as Cathode Material for Rechargeable Lithium Batteries. J. Phys. Chem. C 2008, 112, 16700-16707.

(57) Uchaker, E.; Zhou, N.; Li, Y.; Cao, G. Polyol-Mediated Solvothermal Synthesis and Electrochemical Performance of Nanostructured $\mathrm{V}_{2} \mathrm{O}_{5}$ Hollow Microspheres. J. Phys. Chem. C 2013, 117, 1621-1626.

(58) Pradhan, M.; Roy, A.; Sinha, A. K.; Sahoo, R.; Deb, D.; Pal, T. Solid-state transformation of single precursor vanadium complex nanostructures to $\mathrm{V}_{2} \mathrm{O}_{5}$ and $\mathrm{VO}_{2}$ : catalytic activity of $\mathrm{V}_{2} \mathrm{O}_{5}$ for oxidative coupling of 2-naphthol. DaltonTrans., 2015, 44 ,1889-1899.

(59) Hu, X.; Johnston, W. M. Concentration additivity of coefficients for maxillofacial elastomer pigmented to skin colors. Dent. Mater. 2009, 25, 1468-1473.

(6o) Barron, V.; Torrent, J. Use of the Kubelka-Munk theory to study the influence of iron oxides on soil colour. J. soil Science, 1986, 37, 499-510.

(61) Benmoussa, M.; Outzourhit, A.; Bennouna, A.; Ameziane, E. L. Electrochromism in sputtered $\mathrm{V}_{2} \mathrm{O}_{5}$ thin films: structural and optical studies. Thin Solid Films 2002, 405, 11-16.

(62) Zhang, H.; Wu, Z.; Wu, X.; Yang, W.; Jiang, Y. Transversal grain size effect on the phase-transition hysteresis width of vanadium dioxide films comprising spheroidal nanoparticles. Vacuum 2014, 104, 47-50.

(63) Yoon, J.; Kim, H.; Chen, X.; Tamura, N.; Mun, B. S.; Park, C.; Ju, H. Controlling the Temperature and Speed of the Phase Transition of $\mathrm{VO}_{2}$ Microcrystals. ACS Appl. Mater. Interfaces 2016, 8, 2280-2286.

(64) Ueda, Y.; Kosuge, K.; Kachi, S. Phase Diagram and Some Physical Properties of $\mathrm{V}_{2} \mathrm{O}_{3+x}{ }^{*}(0<\mathrm{x}<0.080)$. J. solid state chem.1980, 31, 171-188. 
(65) Bhowmik, R. N.; Ranganathan, R. Enhancement of surface magnetization in antiferromagnetic nanoparticles.

Solid State Commun. 2007, 141, 365-368. 


\section{TOC}

The vanadium sesquioxide, $\mathrm{V}_{2} \mathrm{O}_{3}$, dioxide $\mathrm{VO}_{2}$ and pentoxide $\mathrm{V}_{2} \mathrm{O}_{5}$ powders were all synthesized from one single polyol route, from annealing in various atmospheres of an intermediate precursor, the vanadium ethyleneglycolte (VEG). In respect of the vanadium oxidation state, magnetic, thermochromic and electrochromic properties are described.

\section{Graphic Highlight}

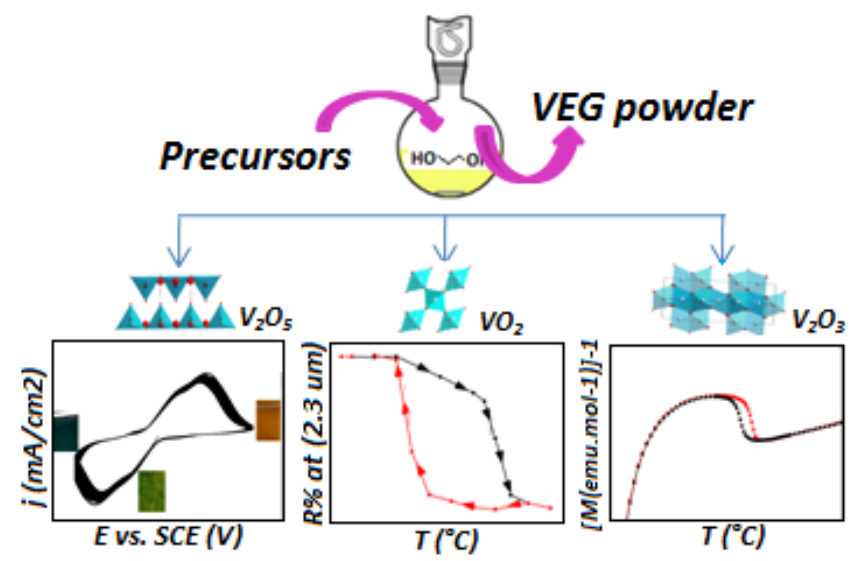

